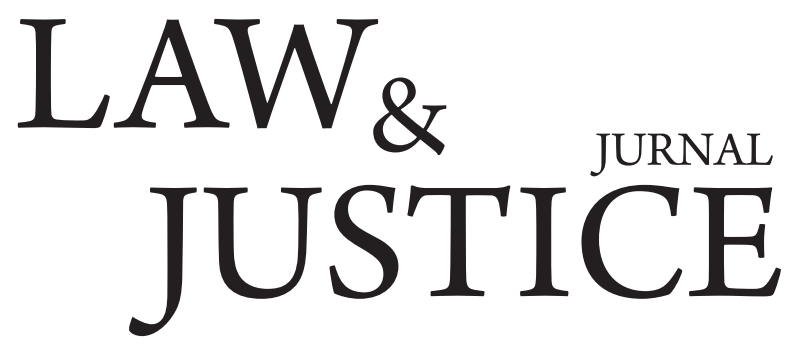

Volume 3, Nomor 2, Oktober 2018

\title{
PENERAPAN KEBIJAKAN HAKIM BERSERTIFIKAT LINGKUNGAN (PEMENUHAN HAK SPIRITUAL HAKIM DALAM MEWUJUDKAN EKOKRASI DI INDONESIA)
}

\author{
Bita Gadsia Spaltani \\ Program Magister Ilmu Hukum \\ Universitas Muhammadiyah Surakarta \\ Email: bgadsia@gmail.com
}

\begin{abstract}
Abstrak
Permasalahan lingkungan di Indonesia telah mencapai tahap yang memprihatinkan. Penyelesaian sengketa lingkungan yang masih jauh dari harapan masyarakat salah satu penyebabnya adalah karena bangunan struktur hukum dan budaya hukum yang lemah. Menanggapi hal tersebut, pada tahun 2011, Mahkamah Agung menerbitkan aturan tentang sertifikasi hakim lingkungan. Dalam Surat Keputusan Mahkamah Agung Nomor 134/KMA/SK/IX/2011 mengharuskan perkara lingkungan hidup ditangani oleh hakim yang bersertifikat lingkungan. Seharusnya dengan hadirnya kebijakan ini, perkara lingkungan dapat terselesaikan di ranah litigasi dengan baik. Tujuan dari penelitian ini adalah untuk menganalisis pelaksanaan kebijakan hakim bersertifikat lingkungan dalam penegakan hukum lingkungan di Indonesia dan mendeskripsikan kebijakan hakim bersertifikat lingkungan dalam pemenuhan hak spiritual hakim dalam mewujudkan ekokrasi di Indonesia. Metode pendekatan yang digunakan dalam penelitian ini adalah metode penelitian hukum doktrinal dengan menggunakan pendekatan undang-undang (statute approach) dan juga pendekatan konseptual (conceptual approach). Selain itu juga digunakan pendekatan kasus (case approach). Digunakan pula pendekatan secara filosofis dalam mengkaji nilai-nilai baik nilai keadilan, nilai kemanfaatan maupun nilai kepastian hukum yang berkaitan dengan permasalahan yang dikaji. Praktek judicial activism bagi hakim yang bersertifikat lingkungan dalam menyelesaikan perkara lingkungan mutlak diperlukan. Mengarah pada pijakan transformatif bagi hakim dalam menyelesaikan sengketa lingkungan dengan perspektif transendental.
\end{abstract}

Kata Kunci: Ekokrasi, hakim bersertifikat lingkungan, hak spiritual, penegakan hukum, sengketa lingkungan

\section{Pendahuluan}

\section{Latar Belakang}

Meningkatnya kasus sengketa lingkungan baik karena pencemaran maupun perusakan lingkungan di Indonesia, membuktikan kebenaran yang dinyatakan Rachel Carson dalam bukunya "The Silent Spring". Sebuah buku yang menggambarkan musim semi yang semula indah, digambarkan menjadi musim 
semi yang sunyi dan menakutkan ${ }^{1}$. Permasalahan lingkungan di Indonesia telah mencapai tahap yang memprihatinkan. Dimulai dengan krisis lingkungan yang mengglobal dengan berbagai musibah, seperti musibah Bhopal, bocornya reaktor nuklir Chernobil, rusaknya lapisan ozon, peristiwa hujan asam, kebakaran, dan rusaknya hutan sampai masalah limbah beracun menjadi momok yang mencemaskan yang menjadikan manusia senantiasa dihinggapi mimpi buruk sebagai akibat perilakunya sendiri. ${ }^{2}$ Problem atau sengketa lingkungan baik di ranah litigasi maupun non litigasi yang melibatkan korporasi-korporasi besar, dengan penegakan hukum lingkungan yang lemah menjadikan permasalahan atau sengketa lingkungan semakin serius dan dapat dikategorikan sebagai extraordinary crime.

Problem lingkungan hidup merupakan masalah khas yang senantiasa akan muncul dalam sistem kehidupan modern yang bercorak kapitalistik.Dalampraktek, aspeklingkungansering kurang mendapat perhatian dalam perencanaan maupun pelaksanaan pembangunan. Di samping itu, banyak juga dijumpai pendirian usaha yang dapat berdampak terhadap lingkungan, namun tidak dilengkapi dengan AMDAL sebagaimana mestinya. Apabila terjadi pencemaran yang merugikan masyarakat dan menimbulkan sengketa lingkungan dengan masyarakat sekitarnya, hampir dipastikan sikap Pemerintah cenderung memihak pada kepentingan pengusaha. Banyak kasus pencemaran yang diadukan pada Pemerintah tidak mendapat perhatian yang semestinya dan tidak ditindaklanjuti penyelesaiannya. ${ }^{3}$

Sengketa lingkungan hidup dapat dikategorikan menjadi tiga, yaitu: 1) sengketa yang berkaitan dengan perlindungan lingkungan; 2) sengketa yang berkaitan dengan pemanfaatan sumber daya alam; 3) sengketa yang muncul akibat pencemaran atau perusakan lingkungan. ${ }^{4}$

1 Rachel Carson, Musim Bunga yang Bisu, Jakarta: Yayasan Obor Indonesia, 1990, hlm. 2. Terjemahan dari Rachel Carson, The Silent Spring, Houghton Miflin, 1962, Penerjemah Budi Kasworo

2 Absori, Penegakan Hukum Lingkungan \& Antisipasi dalam Era Perdagangan Bebas, Surakarta: Muhammadiyah University Press, 2001, hlm. 2

3 Absori, Penegakan Hukum Lingkungan dan Antisipasi dalam Era Perdagangan Bebas, Surakarta: Muhammadiyah University Press, 2001, hlm. 9-14

4 Manventus Amos, La Sina, "Wisnu Wardana, Gugatan Class Action dalam Sengketa Lingkungan Hidup (Tinjauan Yuridis Atas Perma Nomor 1 tahun 2002)",
Penegakan hukum lingkungan di Indonesia telah mendapat perhatian luas, terutama dengan dicanangkannya tahun 1990 sebagai tahun penegakan hukum lingkungan oleh Presiden Soeharto bersama Menteri Lingkungan Emil Salim. Selanjutnya pada tahun 1993, Menteri Lingkungan Sarwono Kusumaatmadja mendorong diberlakukannya kebijakan nasional penegakandan penataan lingkungan tidak selalu mengandalkan pendekatan atur dan awasi (command and control), secara seimbang mengembangkan upaya penataan suka rela, yakni atur diri sendiri dengan penataan suka rela (voluntary compliance). ${ }^{5}$

Penyelesaian sengketa lingkungan yang masih jauh dari harapan masyarakat salah satu penyebabnya adalah karena bangunan struktur hukum dan budaya hukum yang lemah. Hadirnya putusan-putusan dalam sengketa lingkungan yang lebih memihak korporasi merupakan salah satu faktor yang melatarbelakangi lemahnya penegakan hukum lingkungan. Pendekatan positifistis formal menjadikan hakim hanya sebatas memahami peraturan hukum yang ada pada teks perundang-undangan dalam hal ini undangundang lingkungan, dan mengesampingkan prinsip maupun asas-asas hukum lingkungan dengan semata-mata menggunakan pendekatan homocentris dan bukan ecocentris.

Menanggapi hal tersebut, pada tahun 2011, Mahkamah Agung menerbitkan aturan tentang sertifikasi hakim lingkungan. Sertifikasi hakim lingkungan hidup sebenarnya diberikan dalam rangka meningkatkan efektivitas penanganan perkara-perkara lingkungan hidup di ranah litigasi. Hal ini merupakan bagian dari upaya perlindungan lingkungan hidup sekaligus pemenuhan rasa keadilan masyarakat dan juga keadilan ekologis yang hak-haknya semakin terbengkalai di tengah industrialisasi modern dan globalisasi ini. Dalam Surat Keputusan Mahkamah Agung Nomor 134/KMA/SK/IX/2011 mengharuskan perkara lingkungan hidup ditangani oleh hakim yang bersertifikat lingkungan. Seharusnya dengan hadirnya kebijakan ini, perkara lingkungan dapat terselesaikan di ranah litigasi dengan baik. Tetapi nyatanya tidak. Banyak putusanputusan lingkungan yang diselesaikan oleh

Jurnal Beraja Niti, Volume3, Nomor 3, 2014, hlm. 5

5 Koesnadi Hardjasoemantri dan Harry Supriyono, Hukum Lingkungan, Cetakan I, edisi ke-2, Jakarta: Universitas Terbuka, 2006, hlm. 6.4-6.5 
hakim bersertifikat lingkungan yang di dalamnya tetap tidak mencerminkan nilai-nilai ekosentris yang seharusnya lebih banyak diadopsi dalam isi putusan sebagai bagian pertimbangan hakim yang kritis. Padahal dengan hadirnya kebijakan hakim yang bersertifikat lingkungan semestinya membuka ruang penemuan hukum dan akses keadilan (access to justice) yang lebih besar dengan pendekatan hukum yang bersifat progresif sehingga dapat menghasilkan putusan-putusan yang tidak hanya berorientasi pada keadilan masyarakat namun juga pada keadilan ekologi. Pendekatan ekologis bernuansa transendental sehingga menjadikan hakim berpikir selain horisontal namun juga vertikal ke atas sebelum memutus perkara yang berkaitan dengan lingkungan agaknya tidak terlaksana dengan baik. Pemahaman lingkungan dari hakim yang telah dibina dan diberikan sertifikasi lingkungan tidak dibarengi dengan pemupukan nilai-nilai ilahiah dan ekologis secara berbarengan dalam memutus perkara lingkungan hidup. Sehingga penyelesaian sengketa lingkungan hidup menjadi tidak maksimal.

Penelitian terdahulu yang berkaitan dengan hakim dalam penyelesaian kasus lingkungan adalah yang dimuat dalam jurnal internasional yang ditulis oleh the Hon. Justice Brian J Preston SC yang berjudul tentang, "Characteristics of Succesful Environmental Courts and Tribunals". Penelitian ini adalah mengkaji tentang karakteristik-karakteristik apa saja yang dimiliki dalam mewujudkan sebuah pengadilan lingkungan hidup yang sukses, antara lain berkaitan dengan kewenangan yang jelas, peradilan yang bebas dan tidak memihak, yurisdiksi yang memusat dan komprehensif, hakim-hakim yang kompeten di bidang lingkungan, memfasilitasi pengadilan multi-pintu (memfasilitasi ADR), menyediakan akses yang terbuka untuk ahli di bidang scientific dan teknis, akses kepada keadilan lingkungan baik dalam segi putusan maupun prosedur dalam praktik, mewujudkan peradilan yang sederhana, cepat, dan biaya ringan, peradilan yang responsif terhadap permasalahan lingkungan, mengembangkan yurisprudensi tentang permasalahan lingkungan, memiliki misi dan etos yang baik, fleksibel inovatif dan menyediakan fungsi-fungsi tambahan, Selain karakteristik tersebut, dalam mewujudkan peradilan lingkungan yang baik juga dapat mencontoh dalam yurisdiksi- yurisdiksi lain atau terus melakukan perbaikanperbaikan penyelesaian kasus lingkungan yang lebih baik di masa mendatang. ${ }^{6}$

Selain itu penelitian lain yang terkait dengan penegakan hukum lingkungan yang terkendala beban pembuktian masyarakat korban pencemaran lingkungan adalah, dalam praktek gugatan class action di Solo, hasil penelitian yang dilakukan oleh Bambang Yulianto ${ }^{7}$ (2004), tentang gugatan sejumlah masyarakat yang merasa terganggu haknya atas lingkungan hidup, yakni dengan semakin banyaknya pemukiman baru yang ada di sepanjang bantara anak sungai Bengawan Solo dan kalau dibiarkan akan berakibat menimbulkan masalah lingkungan, terutama menimbulkan banjir. Masyarakat menggugat Keputusan Wali Kota atas terbitnya sertifikat hak milik atas tanah, sehubungan banyaknya pemukiman baru sepanjang bantaran Anak Sungai Bengawan Solo. Majelis hakim Pengadilan Negeri Surakarta, yang mengadili perkara tersebut dalam putusannya menyatakan bahwa gugatan yang diajukan sejumlah warga terhadap Keputusan Wali Kota Surakarta yang telah menerbitkan sertifikat hak milik atas tanah untuk sejumlah warga negara di bantaran Anak Sungai Bengawan Solo dengan argumentasi bahwa pihak penggugat tidak memiliki ius standi sebab dianggap sebagai pihak yang tidak secara langsung dirugikan ${ }^{8}$.

Negara Indonesia yang melaksanakan pemerintahan berdasarkan hukum dan nilai-nilai Ketuhanan (teokrasi) serta nilai-nilai demokrasi, guna menjaga keberlanjutan dan keberlangsungan lingkungan (sustainable development) harus pula menjunjung nilai-nilai lingkungan dalam rangka mewujudkan ekokrasi di Indonesia. Konstitusi Indonesia telah mengakui nilai-nilai lingkungan dan hak-hak alam dan seisinya yang diwujudkan dengan green constitution, namun konstitusi di Indonesia yang sudah sedemikian hijaunya juga harus ditunjang dengan payung-payung hukum di bawahnya dalam bingkai green legislation dan juga green budgeting. Dalam implementasinya

6 The Hon. Justice Brian J Preston, "Characteristic of Succesful Environmental Courts And Tribunals," Eco Forum Global Annual Conference Gulyang 2013: The $3^{r d}$ Environmental Justice Seminar, (Juli, 2013), Gulyang, Guizhou, China, pp:52-53

7 Bambang Yulianto, "Gugatan Class Action terhadap Pendirian Bangunan di Sepanjang Bantaran Sungai di Kota Surakarta," Tesis, Program Pascasarjana Universitas Muhammadiyah Surakarta, 2005, hlm. 76 $8 \quad$ Ibid, hlm. 114 
juga harus ditopang dari sisi aparatur penegak hukum terutama lembaga yudisial dalam rangka menghadirkan putusan-putusan yang berkeadilan lingkungan (environment judge). Sinergitas antara peraturan hukum yang pro lingkungan (substansi hukum) dan juga badan kehakiman yang berwawasan lingkungan (struktur hukum), ini harus didukung sedemikian rupa dengan adanya budaya hukum masyarakat yang mempunyai jiwa bangsa (volkgeist) yang tidak hanya bercita-cita pada kesejahteraan masyarakat namun juga pada kelestarian lingkungan.

\section{Perumusan Masalah}

Berdasarkan latar belakang di atas, maka rumusan masalah dalam kajian ini adalah bagaimana pelaksanaan kebijakan hakim bersertifikat lingkungan dalam penegakan hukum lingkungan di Indonesia, dan bagaimana kebijakan hakim bersertifikat lingkungan dalam pemenuhan hak spiritual hakim dalam mewujudkan ekokrasi di Indonesia.

\section{Metode Pendekatan}

Metode pendekatan yang digunakan dalam penelitian ini adalah metode penelitian hukum doktrinal dengan menggunakan pendekatan Undang-Undang (Statute Approach) dan juga pendekatan konseptual (conceptual approach). Penelitian ini dilakukan dengan mengkaji doktrindoktrin hukum, prinsip-prinsip, dan kaidah hukum lingkungan baik yang terdapat dalam literatur, hasil penelitian, maupun putusan hakim di pengadilan. Sebagai suatu bangunan normatif, hukum dikonsepsikan sebagai instrumen untuk menegakkan keadilan yang wujudnya berupa pedoman perilaku dengan fungsi utamanya mengatur perilaku manusia (an instrument of the state or polis concerned with justice, with rules of conduct to regulate human behavior). Hukum merupakan suatu gejala normatif yang bersifat otonom yang terpisah dari gejala sosial. Hukum sebagai sesuatu yang steril (murni) harus dijauhkan dari segala sesuatu yang ada di luar dirinya. Tesis dari aliran hukum ini adalah sparability thesis dan normativity thesis, yakni pemisahan antara hukum dan moralitas dan pemisahan antara hukum dan fakta. Oleh karena itu, norma sebagai sesuatu yang seharusnya tidak identik dengan hal yang ada, dan yang seharusnya merupakan dua modus yang berbeda. Hukum adalah a corceive order. Pandangan ini sering disebut sebagai Reine Rechtslehre atau The pure theory of law (teori hukum murni) yang menekankan pada pembedaan yang tegas antara hukum empiris dan keadilan transendental dengan mengeluarkannya dari lingkup kajian hukum. Tokoh dari aliran ini adalah Hans Kelsen. ${ }^{9}$

Selain itu juga digunakan pendekatan kasus (case approach). Perbedaan antara pendekatan kasus dalam ilmu sosial dan ilmu hukum adalah dilihat dari tujuannya. Ilmu hukum bertujuan untuk mengkaji aturan-aturan hukum dan kaidahkaidahnya baik pada tahap formulasi maupun implikasinya. Meskipun kasus-kasus yang terjadi benar-benar berada di dunia empiris, namun hubungan hukum dengan fenomena yang ada, adalah untuk mendapatkan matra-matra penciptaan aspek normanya, dalam hubungannya dengan hukum secara praktikal. Hasilnya berupa bahan-bahan yang menjelaskan apa sejatinya hukum itu (explanatory of law). ${ }^{10}$ Digunakan pula pendekatan secara filosofis dalam mengkaji nilai-nilai baik nilai keadilan, nilai kemanfaatan maupun nilai kepastian hukum yang berkaitan dengan permasalahan yang dikaji.

\section{Pembahasan dan Analisis}

\section{Pelaksanaan Kebijakan Hakim Bersertifikat Lingkungan dalam Penegakan Hukum Lingkungan di Indonesia}

Ketentuan mengenai lingkungan hidup telah diatur secara normatif di dalam Pasal 28 $\mathrm{H}$ ayat (1) dan juga Pasal 33 ayat (4) UndangUndang Negara Republik Indonesia Tahun 1945. Pasal $28 \mathrm{H}$ ayat (1) Undang-Undang Negara Republik Indonesia Tahun 1945 secara yuridis menyebutkan bahwa, "Setiap orang berhak hidup sejahtera lahir dan batin, bertempat tinggal, dan mendapatkan lingkungan hidup yang baik dan sehat serta berhak memperoleh pelayanan kesehatan." II Selanjutnya Pasal 33 ayat (4)

$9 \quad$ Ahmad Zuhdi Muhdlor, "Perkembangan Metodologi Penelitian Hukum," Jurnal Hukum dan Peradilan, Volume 1, Nomor 2, 2012, hlm. 196

10 Soetadnyo Wignjosoebroto, Pergeseran Paradigma dalam Kajian Sosial dan Hukum, Malang: Setara Press, 2013, hlm. 2

11 Pasal 28 H Ayat (1) Undang-Undang Dasar Negara Republik Indonesia Tahun 1945 
Undang-Undang Negara Republik Indonesia Tahun 1945 menyebutkan bahwa, "Perekonomian nasional diselenggarakan berdasar atas demokrasi ekonomi dengan prinsip kebersamaan, efisiensi berkeadilan, berkelanjutan, berwawasan lingkungan, kemandirian, serta dengan menjaga keseimbangan kemajuan dan kesatuan ekonomi nasional." 12 Kedua pasal inilah yang menjadi konstitusi Negara Indonesia sudah bernuansa hijau, namun hendaknya begitu konstitusi yang sudah hijau (Green Constitution) ini harus ditopang lebih lanjut dengan aturan-aturan hukum di bawahnya yang juga pro lingkungan baik dari Undang-Undang hingga ke Peraturan Daerah (Green Legislation).

Salah satu perwujudan dari adanya penerapan kerangka aturan dasar mengenai lingkungan yang terkonsepsikan dalam konstitusi (green constitution) ke dalam implementasi bentuk peraturan perundang-undangan yang pro lingkungan (green legislation) adalah dengan hadirnya kebijakan Mahkamah Agung yang mengatur mengenai kebijakan hakim bersertifikat lingkungan yang diatur dalam Keputusan Ketua Mahkamah Agung Republik Indonesia Nomor: 36/KMA/SK/III/2015 tentang Perubahan atas Keputusan Ketua Mahkamah Agung Republik Indonesia Nomor 134/KMA/SK/IX/2011 tentang Sertifikasi Hakim Lingkungan Hidup. Hadirnya kebijakan ini mengingat faktor minimnya hakim bersertifikat lingkungan hidup yang menjadi salah satu faktor lemahnya penegakan hukum atau ketidakpuasan masyarakat atas hadirnya putusanputusan pengadilan yang tidak mencerminkan keadilan ekologis terhadap kasus lingkungan hidup. Beberapa contoh kasus penegakan hukum lingkungan yang menimbulkan sorotan dari masyarakat atas putusan-putusan yang tidak mencerminkan keadilan ekosentris adalah sebagai berikut.

Putusan kasus PT. Bumi Mekar Hijau (BMH) yang digugat oleh Kementerian Lingkungan Hidup dan Kehutanan (KLHK) sebesar Rp 7,9 triliun di PN Palembang pada tanggal 30 Desember 2015, hingga kini masih menyisakan rasa ketidakpuasan bagi banyak pihak yang dirugikan. Dalam putusan tersebut, majelis hakim yang diketuai Parlas Nababan S.H., membebaskan PT. BMH dari segala tuntutan KLHK terkait kebakaran yang

12 Pasal 33 Ayat (4) Undang-Undang Dasar Negara Republik Indonesia Tahun 1945 terjadi di konsesi perusahaan tersebut seluas 20 ribu hektare.

Dalam pertimbangan putusannya dalam halaman 114, majelis hakim berpendapat bahwa kerusakan lahan gambut atau lahan basah akibat kebakaran tersebut, dihubungkan dengan hasil pengamatan lapang dan hasil laboratorium sebagai scientific evidence bahwa tidak ada indikasi bahwa tanah telah rusak, lahan masih berfungsi dengan baik sesuai dengan peruntukannya sebagai lahan hutan tanaman industri, di atas bekas lahan yang terbakar tersebut tanaman akasia dapat tumbuh kembali secara baik, sebagaimana penglihatan Majelis ketika melakukan sidang pemeriksaan di tempat. Majelis Hakim juga berdalih bahwa dalil penggugat yang menyatakan bahwa pada lahan yang terbakar terdapat kawasan lindung gambut berdasarkan alat bukti perkara, dinyatakan bahwa kawasan konsensi PT. BMH yang terbakar tidak terdapat hutan lindung, melainkan kawasan konsesi PT. BMH dulunya adalah hutan terdegradasi akibat kebakaran pada el-Nino tahun 1997. ${ }^{13}$

Bahwa pertimbangan hakim selanjutnya tentang kerugian ekologis, dengan kebakaran yang terjadi tidak menyebabkan peningkatan $\mathrm{pH}$ maupun unsur hara lain seperti $\mathrm{Ca}, \mathrm{Mg}$, dan $\mathrm{K}$, kebakaran yang terjadi memang menurunkan kandungan organik tanah namun tidak sampai menyebabkan kepunahan atau kerusakan sifat biologis tanah. ${ }^{14}$

Dengan pertimbangan hakim yang menggunakan logika semuanya jika berlanjut bagi kasus-kasus lingkungan hidup ke depan yang telah masuk dalam extraordinary crime akan memberikan preseden buruk bagi penegakan kasus lingkungan hidup di masa depan. Selain itu materi gugatan yang disampaikan oleh KLHK juga lemah sebab dalam gugatan tidak disebutkan dampak yang ditimbulkan dari kabut asap tersebut namun justru kerusakan lahan. Sehingga memunculkan analogi hakim yang salah bahwa selama tidak ada kepunahan sifat biologis tanah dan hanya berkurang kandungan organiknya dan selama tanah tersebut masih bisa ditanami tumbuhtumbuhan, maka tidak ditemukan kerusakan yang serius.

Setelah kandas di Pengadilan Negeri (PN Palembang) gugatan Menteri Lingkungan Hidup

13 Putusan Pengadilan Nomor 24/Pdt. G/2015/PN.Plg 14 Ibid 
dan Kehutanan (LHK) atas PT Bumi Mekar Hijau sebesar Rp 7,9 miliar akhirnya tidak siasia di tingkat banding. Memori banding berisi agar hakim yang akan mengadili menggunakan argumen hukum prinsip tanggung jawab mutlak (strict liability). Pembuktian dilakukan secara terbalik atau perusahaan harus bertanggung jawab secara hukum tanpa perlu dibuktikan perbuatannya sengaja atau lalai. Hal ini sebagaimana dijelaskan dalam Pasal 88 UU No. 32 Tahun 2009 yang menyatakan bahwa, "Setiap orang yang tindakannya, usahanya, dan/atau kegiatannya menggunakan B3, menghasilkan dan/atau mengelola limbah B3, dan/atau yang menimbulkan ancaman serius terhadap lingkungan hidup bertanggung jawab mutlak atas kerugian yang terjadi tanpa perlu pembuktian unsur kesalahan".

Pengadilan Tinggi (PT) Palembang akhirnya mengabulkan banding yang diajukan Menteri LHK atas putusan PN Palembang tersebut. Majelis hakim PT Palembang yang dipimpin hakim ketua Mabruq Nur dengan hakim anggota Agus Hariyadi dan Muzaini Achmad dalam amar putusannya atas perkara Nomor 51/Pdt/2016/PT.Plg tahun 2016 menyebutkan, "Menerima permohonan banding dari Penggugat atau Pembanding dan Membatalkan putusan Pengadilan Negeri Palembang Nomor: 24/Pdt.G/2015/PN.Plg tanggal 30 Desember 2015, yang dimohonkan banding tersebut." 15

Majelis hakim yang dipimpin Mabruq Nur yang juga Ketua PT Palembang juga memutuskan dengan mengadili sendiri, menolak tuntutan provisi Penggugat / Pembanding. Dalam eksepsi menolak eksepsi Tergugat / Terbanding. Kemudian dalam pokok perkara menerima dan mengabulkan gugatan Penggugat / Pembanding untuk sebagian, menyatakan Tergugat/Terbanding telah melakukan perbuatan melawan hukum, menghukum Tergugat / Terbanding untuk membayar ganti rugi sebesar Rp. 78.502.500.000,00 (tujuh puluh delapan milyar lima ratus dua juta lima ratus ribu rupiah) kepada Penggugat atau Pembanding melalui rekening Kas Negara, menghukum Tergugat / Terbanding untuk membayar biaya perkara ini dalam kedua tingkat peradilan yang dalam tingkat banding sebesar Rp. 150.000,-, dan menolak gugatan Penggugat / Pembanding untuk yang selebihnya. ${ }^{16}$ Dengan adanya putusan banding yang menolak putusan

15 Putusan Pengadilan Nomor 51/Pdt/2016/PT. Plg
16 Ibid. sebelumnya, maka Tergugat/ Terbanding yang merupakan korporasi dijatuhi hukuman untuk membayar ganti rugi sebesar Rp 78 milyar rupiah, dan seharusnya ganti rugi yang dibayarkan sesuai dengan kerugian ekologis yang diakibatkan akibat pembakaran lahan tersebut dan dapat dikembalikan seperti semula.

Mengenai dampak lingkungan yang diakibatkan oleh asap dari kebakaran hutan tersebut juga meluas hingga ke negara tetangga, Singapura. Dampak yang terjadi tersebut dapat menjadi dasar dalam meminta pertanggung jawaban negara atas dasar telah melakukan tindakan yang merugikan negara lain, dimana Indonesia harus mengambil penanganan cepat dalam menuntaskan masalah serius kebakaran hutan tersebut, dimana asas tanggung jawab negara ini menjadi salah satu landasan dalam perlindungan dan pengelolaan lingkungan hidup yang terdapat dalam Pasal 2 UU No. 32 tahun 2009 tentang Perlindungan dan Pengelolaan Lingkungan Hidup.

Selain itu masalah pembangunan masalah kehutanan yang berkelanjutan juga telah diatur di dalam Foresty Principle, yang merupakan konsensus internasional mengenai pembangunan kehutanan berkelanjutan yang terdiri dari 15 prinsip yang berkaitan dengan perlindungan, pengelolaan, dan pemanfaatan sumber daya hutan secara berkelanjutan, yang bersifat tidak mengikat secara hukum (non legally binding) dan berlaku untuk semua jenis hutan. Kendati demikian, dokumen ini menjadi dasar bagi perundingan lebih lanjut tentang persetujuan internasional di bidang kehutanan. Pernyataan prinsip-prinsip kehutanan yang terdapat dalam foresty principle, di antaranya negara memiliki kedaulatan penuh untuk mengelola hutannya sepanjang tidak menimbulkan kerusakan lingkungan, kebijaksanaan nasional harus mencerminkan pengelolaan hutan secara berkelanjutan, termasuk di dalamnya konversi lahan hutan bagi pembangunan sosial ekonomi, sesuai dengan tata guna lahan yang rasional, kebijaksanaan dan strategi nasional harus mampu meningkatkan upaya pembangunan, kelembagaan, dan program pengelolaan hutan, kebijaksanaan dan strategi tersebut harus memperhatikan kelangsungan ekosistem hutan dan sumber daya alam serta mempertimbangkan faktor-faktor di luar sektor hutan. ${ }^{17}$

17 Muhammad Akib, Hukum Lingkungan Perspektif Global dan Nasional, Jakarta: PT. Raja Grafindo 
Putusan di PN Palembang yang diketuai oleh Parlas Nababan dengan hakim anggota Eli Warti dan Kartijono yang memenangkan korporasi dengan dalih kebarakan lahan bisa ditanam kembali. Ternyata ketiga hakim tersebut telah bersertifikat lingkungan namun tidak dibarengi dengan putusan yang mencerminkan keadilan ekologis. Hal ini tentu menimbulkan hal yang berkebalikan sebab seharusnya hakim yang telah bersertifikat lingkungan lebih mengedepankan pertimbangan-pertimbangan ekologis daripada logika abstrak. Mahkamah Agung dalam hal ini diharapkan lebih meningkatkan evaluasi terhadap sertifikasi hakim lingkungan hidup dan juga memperkuatnya dalam sisi pembinaan materi sebelum menjatuhkan putusan lingkungan hidup.

Penegakan hukum lain yang terkait dengan kasus lingkungan hidup yang menyita perhatian publik adalah terkait dengan kasus gugatan Masyarakat Rembang melawan PT. Semen Indonesia Tbk. Sengketa ini bermula dari keluarnya SK Gubernur Jawa Tengah yang memberikan izin lingkungan terhadap PT Semen Indonesia pada tahun 2012 lalu. Surat Keputusan Gubernur Jawa Tengah Nomor 660.1./17 tahun 2012 tentang Izin Lingkungan Kegiatan Penambangan dan Pembangunan Pabrik Semen oleh PT Semen Gresik (Persero) Tbk menuai resistensi dari masyarakat Rembang. SK tersebut dinilai bertentangan kaitannya dengan sosialisasi amdal dan penetapan area cekungan air tanah sebagai kawasan resapan air serta penggunaan kawasan hutan lindung geologi yang dinilai tidak memenuhi prinsip pembangunan berkelanjutan.

Dalam sengketa ini, Gubernur Jawa Tengah sebagai tergugat I dan tergugat II yakni PT Semen Indonesia (SI) Persero Tbk di Rembang. Penggugat adalah warga Rembang yang diwakili Joko Prihanto beserta Wahana Lingkungan hidup Indonesia. Kasus Rembang yang telah sampai ke kasasi hingga ke PK tersebut menyita perhatian publik dan mengundang resistensi yang kuat dari masyarakat Rembang. Hal ini dikarenakan pasca putusan MA No. 99 PK/TUN/2016 tertanggal 5 Oktober 2016 tidak membuat pengoperasian pabrik semen berhenti sebab Gubernur kembali mengeluarkan izin lingkungan yang baru bagi PT Semen Indonesia. Hal ini menuai resistensi dalam bentuk aksi demonstrasi dari masyarakat Rembang yang menuntut agar izin lingkungan

Persada, 2013, hlm. 21 beserta dengan izin usaha pabrik tersebut dicabut dan dihentikan. Dari fakta di lapangan, gejala akan terjadi kerusakan ekologis, konflik budaya, dan agama di tengah industri semen ini sudah terbaca dari suasana sosialisasi industri semen gresik yang diwarnai dengan konflik akar rumput yang melahirkan klasifikasi masyarakat tolak dan masyarakat pro semen. ${ }^{18}$

Seharusnya berdasarkan UU tersebut, terkait dengan SK Gubernur No. 660.1/17 tahun 2012 yang telah dicabut berdasarkan amar putusan MA, pemerintah tidak kembali mengeluarkan izin lingkungan baru dengan alasan perubahan pengelolaan dan pemantauan lingkungan. Pemberian izin pembangunan pabrik Semen Indonesia di Rembang seharusnya dicabut dan dibatalkan dengan lebih mengutamakan prinsip keadilan sosial-ekologis, pemerataan, dan keberlanjutan kelestarian alam.

Berkaitan dengan penanganan kasus Rembang yang diawali dengan gugatan di PTUN Semarang, sebelumnya Walhi dalam hal ini sebagai salah satu pemohon gugatan sebelumnya telah mengajukan permohonan kepada Kepala TUN Semarang, agar sidang dipimpin oleh majelis hakim dengan sertifikat hakim lingkungan hidup. Permohonan Walhi didasarkan Keputusan MA No. 36/KMA/SK/II/2013 tentang pemberlakuan pedoman penanganan perkara lingkungan hidup dimana pada Pasal 21 disebutkan bahwa perkara lingkungan hidup pada tingkat pertama dan pengadilan tingkat banding di lingkungan peradilan umum dan PTUN harus diadili dengan ketua majelis hakim bersertifikat lingkungan. Meskipun hal tersebut sudah dilakukan, nampaknya penjatuhan putusan di PTUN Semarang masih jauh dari harapan masyarakat. Putusan sama sekali tidak menilik pokok perkara, hakim lebih memperhatikan aspek prosedural dengan dalih gugatan yang telah kadaluarsa.

Dalam kajian filosofis, berkaitan dengan penegakan hukum bahwa hukum harus didasarkan pada pemahaman yang proporsional mengenai dua sumber otoritas yang bersifat mutlak dan relatif. Sumber otoritas hukum adalah ajaran-ajaran agama sementara sumber otoritas relatif adalah perilaku dan pendapat legal para ahli hukum. Oleh karena itu. penegakan hukum harus mempertimbangkan

18 U. Achmad, 2015, "Masyarakat Santri dan Revolusi Industri Pertambangan di Rembang dalam Perspektif Politik Ibn Khaldun," Jurnal J.Addin, Volume 9, Nomor 1, hlm. 129-160 
integritas penegak hukumnya dalam hubungannya dengan nasib seseorang. Dalam hubungan dengan hukum transendental, hukum harus melakukan perbaikan-perbaikan untuk menguatkan dirinya agar ketetapannya tidak kehilangan sentuhan dengan sejarah manusia. Dalam hubungannya dengan takdir, dipahami bahwa satu cabang pengetahuan atau paradigma tidak akan selamanya menyelesaikan masalah. Seorang ilmuwan harus menerima adanya keterbatasan manusia untuk mengerti dan memahami semua hal. Dalam konteks hukum transendental berarti hukum dan penegakan hukum harus mempertimbangkan aspek-aspek ekstra-legal yang dengan cara itulah hukum menjadi bagian dari simpul multiperspektif kaidah-kaidah keilmuan. ${ }^{19}$

Penegakan hukum lingkungan yang dilakukan lembaga formal, seperti pengadilan dan pemerintah yang selama ini belum bergesar dari pendekatan positivis formal dan prosedural. Aparat penegak hukum dalam merespon dan menyelesaikan berbagai persoalan lingkungan menunjukan sikap yang formalis, deterministik, dan memberi peluang terjadinya perilaku eksploitatif di kalangan pelaku usaha (investor). Instrumen hukum yang dipakai hanya berorientasi prosedur dan tidak dapat diandalkan sebagai pilar utama untuk mengatasi problem lingkungan, sementara pencemaran lingkungan dalam proses waktu semakin sulit untuk dapat dikendalikan. Untuk mengatasinya perlu dilakukan gerakan penyadaran secara progresif dengan melibatkan pertisipasi masyarakat, aparat penegak hukum, dan pemerintah akan tugas dan tangung jawabnya dalam menyelesaikan dan memecahkan masalahmasalah lingkungan. Dalam konteks ini untuk dapat menjalankan hukum lingkungan di tengah masyarakat yang penuh dengan kompleksitas, dibutuhkan aparat penegak hukum, yakni polisi, jaksa, dan hakim yang mempunyai visi, komitmen yang kuat, dan pengetahuan yang memadai di bidang lingkungan. Oleh karena itu, sudah saatnya perlu dilakukan rekrutmen dan pembinaan aparat penegak secara khusus, yang nantinya diharapkan dapat menjalankan tugas khusus dalam menangani sengketa ataupun pengaduan masyarakat masalah lingkungan, berupa perusakan atau pencemaran lingkungan. Hakim yang diangkat atau ditunjuk

19 Absori, "Epistemologi dan Legalisasi Hukum Transendental," Hukum Transendental Pengembangan dan Penegakan Hukum di Indonesia, hlm. 31 dapat saja direkrut dari kalangan akademisi atau pakar hukum lingkungan, praktisi yang mengetahui seluk-beluk masalah lingkungan, ataupun kalangan aktivis yang selama ini gigih memperjuangkan lingkungan. ${ }^{20}$

Dalam kajian filosofis, berkaitan dengan penegakan hukum bahwa hukum harus didasarkan pada pemahaman yang proporsional mengenai dua sumber otoritas yang bersifat mutlak dan relatif. Sumber otoritas hukum adalah ajaran-ajaran agama sementara sumber otoritas relatif adalah perilaku dan pendapat legal para ahli hukum. Oleh karena itu, penegakan hukum harus mempertimbangkan integritas penegak hukumnya dalam hubungannya dengan nasib seseorang. Dalam hubungan dengan hukum transendental, hukum harus melakukan perbaikan-perbaikan untuk menguatkan dirinya agar ketetapannya tidak kehilangan sentuhan dengan sejarah manusia. Dalam hubungannya dengan takdir, dipahami bahwa satu cabang pengetahuan atau paradigma tidak akan selamanya menyelesaikan masalah. Seorang ilmuwan harus menerima adanya keterbatasan manusia untuk mengerti dan memahami semua hal. Dalam konteks hukum transendental berarti hukum dan penegakan hukum harus mempertimbangkan aspek-aspek ekstra-legal yang dengan cara itulah hukum menjadi bagian dari simpul multiperspektif kaidah-kaidah keilmuan. ${ }^{21}$

Membicarakan konsep penegakan hukum dari tinjauan filsafat hukum dapat dikaji dari faktor penegak hukum khususnya hakim sebagai manusia yang akan memahami nilai-nilai hukum yang hidup dalam masyarakat. Hakim dalam kaitannya dengan penegakan hukum adalah dua hal yang saling berkaitan dan tidak dapat dipisah-pisahkan yaitu "hukum dan keadilan", sebagaimana seorang filsuf hukum terkemuka Gustav Radbruch menjelaskan bahwa: "Hukum itu adalah hasrat kehendak untuk / demi mengabdi pada keadilan." Lebih lanjut, pada dasarnya tugas hakim dalam penegakan hukum melalui penemuan hukum yang dilakukan hakim dituntut untuk melakukan penafsiran terhadap realitas dalam memberikan putusan yang adil berdasarkan kebenaran dan mewujudkan rasa keadilan itu sendiri dengan menggunakan hati nurani. Hati nurani ini penting

20 Absori, "Penegakan Hukum Lingkungan pada Era Reformasi," Jurnal Ilmu Hukum, Volume 8, Nomor 2, 2005, hlm. 233-234

21 Absori, "Epistemologi dan Legalisasi Hukum Transendental," Op. Cit., hlm. 31 
sebagai faktor yang dapat mencegah dan menjaga penemuan hukum yang harus ditingkatkan dan diasah terus sehingga mampu menerima hidayah dari Tuhan.

\section{Kebijakan Hakim Bersertifikat Lingkungan dalam Pemenuhan Hak Spiritual Hakim dalam Mewujudkan Ekokrasi di Indonesia.}

Penerapan kebijakan hakim bersertifikat lingkungan di Indonesia dengan pembinaan hakim secara simultan oleh Mahkamah Agung sebelum diberikannya sertifikasi tentang wawasan lingkungan, merupakan sebuah terobosan langkah maju lembaga yudisial dalam rangka pengakuan terhadap nilai-nilai lingkungan dimana lingkungan memiliki hak-haknya sendiri di antara relasi dengan manusia. Sehingga hal ini merupakan langkah progresif dalam rangka mewujudkan apa yang disebut ekokrasi di Indonesia.

Sehubungan dengan hal tersebut, terkait dengan perilaku hakim dengan budaya hukum (legal culture). Lawrence M. Friedman memasukkan unsur budaya hukum (legal culture) sebagai salah satu unsur penting dalam bangunan sistem hukum. Sebelumnya, pandangan kaum positivis-legalistik menganggap hukum positif sebagai unsur yang utama dalam bangunan sistem hukum. ${ }^{22}$ Dalam praktek litigasi saat ini, hadirnya beragam putusan hakim dengan pertimbangan hukum positivis-legalistik dalam penanganan sengketa lingkungan dan kurang memperhatikan keadilan ekologis sebagai sarat pendekatan hukum yang dipakai oleh hakim tentu tidak dapat mewujudkan keadilan dari sisi ekologis. ${ }^{23}$

Pengadilan yang terikat oleh norma umum yang menentukan prosedur sebagaimana pula isi keputusannya, memungkinkan pula adanya legislator yang mengotorisasi pengadilan dalam memutuskasus konkretberdasarkan keyakinannya. Hakim merupakan legislator dimana isi putusan yang dibuat tidak pernah dapat ditentukan secara konkret berdasarkan norma hukum substantif

22 Achmad Ali, Menguak Teori Hukum (Legal Theory) dan Teori Peradilan (Judicialprudence) Termasuk Interpretasi Undang-Undang (Legisprudence), Jakarta: Kencana Prenada Media Group, 2009, hlm. 225

23 Rochmani, Safik Faozi, Adi Suliantoro, "Budaya Hukum Hakim dalam Penyelesaian Perkara Lingkungan Hidup di Pengadilan”, Prosiding Seminar Nasional Multi Disiplin Ilmu \& Call For Papers Unisbank Ke-2, Unisbank Semarang, 28 Juli 2016, hlm. 3 yang ada. Putusan yang telah dijatuhkan juga tidak terlepas dari adanya penilaian masyarakat atau pihak-pihak yang berkepentingan untuk menilai apakah putusan yang dijatuhkan sudah sesuai dengan asas keadilan, kemanfaatan dan kepastian hukum untuk kemudian diputuskan perlu adanya eksaminasi putusan atau tidak.

Suatu putusan hakim harus adil, tetapi harus pula bermanfaat bagi yang bersangkutan maupun bagi masyarakat, dan terjamin kepastian hukumnya. Dalam praktiknya, dapat dikatakan tidak mungkin untuk menghadirkan ketiga unsur Idee des Rechts itu secara proporsional dalam suatu putusan. Sering terjadi ketegangan atau konflik antara ketiga unsur itu. Dalam hal terjadi konflik antara keadilan dan kepastian hukum, maka hakim berdasarkan Freies Ermessen-nya (kebebasannya) dapat memilih keadilan dengan mengabaikan kepastian hukum sepanjang tidak bertentangan dengan kepentingan umum atau negara. Di sini hakim harus lebih mengutamakan kepentingan pihak yang bersangkutan daripada kepastian hukum, tetapi tidak bertentangan dengan kesusilaan, kepentingan umum, atau negara. Pemikiran ini dikenal sebagai problem oriented thinking. Ada suatu ungkapan yang berbunyi summum ius summa injuria, yang berarti: makin lengkap, rinci, atau ketat peraturan hukumnya, maka keadilannya makin terdesak atau ditinggalkan, sehingga keadilan harus didahulukan dari kepastian hukum. Bunyi irah-irah atau titel eksekutorial setiap putusan pengadilan adalah "Demi Keadilan berdasarkan Ketuhanan Yang Maha Esa"24.

Berjalannya sistem kenegaraan Republik Indonesia mengenai konsepsi kedaulatan, keempat ajaran baik ajaran kedaualatan Tuhan, kedaulatan hukum, kedaulatan rakyat dan juga kedaulatan lingkungan berlaku secara simultan, bersinergi dan berkesinambungan dalam pergumulan pemikiran bangsa Indonesia tentang kedaulatan. Kekuasaan kenegaraan dalam bingkai Negara Kesatuan Republik Indonesia merupakan derivasi dari kesadaran kolektif dalam jiwa kebangsaan kita mengenai kemahakuasaan Tuhan Yang Maha Esa. Keyakinan terhadap landasan filosofis yang bercorak divinatoris yang mengakui kekuasaan Tuhan terwujud dalam dimensi paham kedaulatan hukum sekaligus paham kedaulatan rakyat yang

24 Sudikno Mertokusumo, Teori Hukum (Edisi Revisi), Yogyakarta: Cahaya Atma Pustaka, 2014, hlm. 23-24 
diterima sebagai landasan berpikir sistemik dalam konstruksi UUD negara kita. Prinsip kedaulatan hukum yang terlembagakan dalam dua sistem hukum baik rechtstaat atau the rule of law dalam bingkai kenegaraan Indonesia selanjutnya terimplementasikan dalam mekanisme demokrasi kerakyatan di barengi dengan pelaksanaan sila keempat Pancasila, yakni kerakyatan yang dipimpin oleh hikmah kebijaksanaan dalam permusyawaratan perwakilan. $^{25}$ Sementara itu kedaulatan lingkungan telah terkonsepsikan dengan baik di dalam rumusan dasar negara yang merupakan pengakuan atas hak-hak dasar alam / lingkungan. Perlu adanya sinergitas secara simultan di antara keempat ajaran kedaulatan tersebut terutama dalam penyelesaian sengketa lingkungan hidup.

Paham kedaulatan Tuhan harus diikutsertakan dalam pengkajian paradigmatik dalam menyelesaikan sengketa lingkungan hidup yang disebabkan oleh pola hubungan yang tidak seimbang antara manusia dan alam. Dengan mengakui kehadiran Tuhan Yang Maha Kuasa, manusia dipaksa untuk bertindak adil terhadap sesama makhluk hidup. Sudah saatnya, lingkungan juga dianggap sebagai subjek hukum. Alam mempunyai hak-hak dasar atau hak-hak asasinya sendiri untuk tidak dirusak dan diganggu keseimbangannya ${ }^{26}$ Artinya pada alam diakui adanya kekuasaan yang tidak boleh dilanggar siapapun (inalienable rights), alam diakui memiliki kedaulatan, inilah yang dinamakan sebagai prinsip kedaulatan lingkungan sebagai wujud dari ekokrasi. Dalam hal ini hakim sebagai wakil Allah merupakan representasi dari kehadiran Tuhan Yang Maha Esa yang diberikan wewenang (kekuasaan) dalam menjalankan hak-hak dasar alam (lingkungan), sehingga dapat diperoleh keadilan lingkungan.

Dalam penyelesaian sengketa lingkungan, dibutuhkan putusan-putusan hakim dengan pendekatan ilahiah (teosentris) dan juga pendekatan ekologis. Kebijakan mengenai hakim bersertifikasi lingkungan yang sudah berjalan di Indonesia merupakan kebijakan yang terus dijaga dan juga dikawal sebagai solusi kapabiltas hakim. Sertifikasi hakim lingkungan telah dilaksanakan

25 Jimly Asshiddiqie, Konstitusi dan Konstitusionalisme Indonesia, Jakarta: Sinar Grafika, 2017, hlm. 136

26 Jimly Asshiddiqie, Green Constitution (Nuansa Hijau Undang-Undang Dasar Negara Republik Indonesia Tahun 1945), Jakarta: Rajawali Pers, 2009, hlm. 120
Mahkamah Agung sejak tahun 2011 yang bekerja sama dengan Kementerian Lingkungan Hidup, dengan dikeluarnya Surat Keputusan Ketua Mahkamah Agung RI Nomor: 134/KMA/SK/ IX/201127 tentang Sertifikasi Hakim Lingkungan sebagai langkah pembaharuan sistem sertifikasi hakim lingkungan dalam menangani perkara tata usaha negara di bidang lingkungan hidup. Hingga saat ini, MA telah memiliki 210 lebih hakim bersertifikat lingkungan dengan dilaksanakannya pelatihan dan pembinaan setiap tahun, namun pada tanggal 19 Maret 2015 lalu, MA mengubah kembali SK MA No. 134/2011 dengan mengeluarkan SK MA No. 36/ $2015^{28}$ yang isinya menyatakan bahwa perkara lingkungan tidak lagi harus dipimpin hakim bersertifikat lingkungan dengan pertimbangan keterbatasan anggaran. Hal ini merupakan langkah mundur Mahkamah Agung. Hakim bersertifikasi lingkungan harus tetap dipertahankan sebab merupakan tonggak bagi keluarnya putusan-putusan yang ekosentris. Masalah anggaran tidak dapat dijadikan alasan. Jika perlu ke depan diupayakan pembentukan payung hukum yang secara khusus mengatur mengenai model pengadilan khusus untuk lingkungan, sebab kasus lingkungan termasuk dalam extraordinary crime yang mendesak untuk diimplementasikan mengingat masalah lingkungan setiap tahun semakin mendesak dan kompleks.

Dalam kaitan dengan hakim bersertifikat lingkungan, KLH juga harus terus berkoordinasi dengan MA mengenai pembinaan hakim bersertifikasi lingkungan. Bahwa dalam pembinaan lingkungan ke depan, hakim juga harus dibina dengan pendekatan spiritual, sesuai amanat hakim yang menjatuhkan putusan berdasarkan pada "Demi Keadilan Berdasarkan Ketuhanan Yang Maha Esa". Sehingga hakim akan bertindak sebagai wakil Allah dalam menyelesaikan kasus sengketa lingkungan hidup sehingga dapat memberikan putusan yang adil. Sehingga kebijakan hukum di bidang lingkungan harus diarahkan dalam perkembangan kepada tingkat kesempurnaan yang lebih baik.

Sasaran perlindungan hukum dalam penegakan hukum administrasi lingkungan oleh Peradilan TUN selain locus atau lingkungan

\footnotetext{
27 Surat Keputusan Ketua Mahkamah Agung RI Nomor: 134/KMA/SK/IX/2011

28 Surat Keputusan Ketua Mahkamah Agung RI Nomor:
} 36/KMA/SK/IX/2015 
dalam artian habitat juga lingkungan dalam arti keberlangsungan makhluk hidup dalam kesatuan ekosistem selain manusia (naturlijk person) dan badan hukum sebagai bagian dari subjek hukum selain manusia. Pengakuan manusia sebagai subjek hukum terhadap eksistensi dan keberlangsungan makhluk hidup merupakan refleksi dan derivasi atas kesadaran adanya persamaan hak dan pengakuan hukum berdasarkan hukum terhadap semua makhluk hidup (legal right for natural objects). Sehingga tujuan lain penegakan hukum lingkungan adalah dalam rangka menjaga kelestarian dan keseimbangan lingkungan dan keadilan antar generasi (inter-generational equity) dengan perspektif atau pendekatan keseimbangan antara prinsip pemanfaatan dan pengelolaan dengan prinsip perlindungan lingkungan hidup. ${ }^{29}$

Dalam hukum lingkungan dikenal adanya doktrin in dubio pro natura dimana maknanya apabila dalam suatu perkara lingkungan, hakim mengalami problem keragu-raguan mengenai kualitas pembuktian dan keyakinan hakim itu sendiri, maka hakim mengedepankan perlindungan lingkungan dalam putusannya. Dalam penyelesaian sengketa lingkungan, langkah-langkah perlindungan lingkungan diutamakan meskipun terdapat ketidakpastian ilmiah terhadap dampak negatif suatu kegiatan yang mempengaruhi kelangsungan dan mutu lingkungan hidup. Doktrin in dubio pro natura ini terutama digunakan berkaitan dengan prinsip kehati-hatian (precautionary principle) yang dikonsepsikan dalam Deklarasi Rio Tahun 1992. ${ }^{30}$

Kerusakan lingkungan yang semakin parah, mengglobal dan terus menerus dalam jumlah massif. Pemanasan global, kekeringan panjang, kebakaran hutan, pencemaran sungai, kelangkaan airbersih, sertaancamansenjatabiologismerupakan serangkaian deret permasalahan lingkungan di dalam siklus berantai yang tidak kunjung selesai dan dalam jangka waktu yang lama mengakibatkan dampak yang buruk dan mengancam kehidupan umat manusia di masa depan. Upaya pemihakan atas isu lingkungan memiliki agenda, di mana isu penyelematan ekologi memiliki posisi ang sama dengan penguatan demokrasi. Asumsi dasarnya adalah apabila demokrasi yang berlandaskan pada

29 Enrico Simanjuntak, Hukum Acara Peradilan Tata Usaha Negara (Transformasi dan Refleksi), Jakarta: Sinar Grafika, 2018, hlm. 332

$30 \quad$ Ibid., hlm. 333 kedaulatan rakyat maka agenda penyelematan ekologi berbasis atau berlandas pada kedaulatan alam atau kedaulatan lingkungan. Konsepsi perjuangan mewujudkan kedaulatan ekologi inilah yang kemudian disebut sebagai ekokrasi.

Salah seorang pemikir yang mencoba menukik dalam ke persoalan filosofis adalah Henryk Skolimowski. Skolimowski adalah profesor filsafat pada Department of Humanities, University of Michigan, Ann Arbor. Ia lebih lanjut berpendapat:

\section{"Without philosophy, we have no anchor, no direction, no sense of the meaning of life. Each epoch and each society is rooted in some fundamental beliefs and assumptions, which are acted upon as if they were true. They justify all other things that follow from them, while they themselves are accepted on faith. "'31}

Skolimowski mencoba menawarkan filsafat lingkungan sebagai suatu tantangan yang memiliki persoalan-persoalan yang cukup signifikan untuk membuat para filsuf dan juga para pemikir hukum kritis dalam merefleksikan dan mengkaji ulang postulat-postulat baru. Ia mengajukan satu garis besar filsafat baru, yaitu filsafat lingkungan yang mengkaji dan merefleksikan hubungan antara individu dengan lingkungan. Filsafat lingkungan menurut Skolimowski berusaha melakukan rekonstruksi menyeluruh pada kosmologi kita yang melingkupi aspek kebudayaan dan menyusun kembali koherensi sistem nilai manusia dan cara pandangnya terhadap alam semesta. ${ }^{32}$ Dalam alur gagasan yang dikonsepsikan Skolimowski ekokrasi bisa dikatakan sebagai 'pengembangan lebih jauh' dari demokrasi karena memang melibatkan alam dan hak-haknya dalam dinamika kehidupan yang lebih baik. Secara konseptual, ekokrasi lebih dalam dari demokrasi ekologis, atau demokrasi yang berwawasan ekologi sebab dalam demokrasi ekologis pusatnya tetaplah manusia.

31 Henryk Skolimowski, "Eco-philosophy: Designing New Tactics for Living" dalam Eko Nurmardiansyah, "Eco-Philosophy dan Implikasinya dalam Politik Hukum Lingkungan di Indonesia," Jurnal Melintas, Volume 30, Nomor 1, 2014, hlm. 79

32 Eko Nurmardiansyah, "Eco-Philosophy dan Implikasinya dalam Politik Hukum Lingkungan di Indonesia," Jurnal Melintas, Volume 30, Nomor 1, (2014), hlm. 80-81 
Dalam rumusan Skolimowski ekokrasi merupakan "pengakuan kekuatan alam dan hidup itu sendiri, yang berarti mengobservasi keterbatasan alam, mendesain dengan alam, membuat sistem yang berkelanjutan secara ekologis, penghormatan terhadap alam dan lingkungan." ${ }^{33}$

Dalam setiap etape itu akan ada beberapa tanjakan yang perlu diperhatikan. Pada ranah filosofis atau etape pertama, ada tiga tanjakan besar. Tanjakan pertama adalah tanjakan yang paling rumit dan menentukan, yaitu memahami dan merumuskan eksistensi alam dan bagianbagiannya. Tanjakan kedua, terkait erat dengan tanjakan pertama, adalah merumuskan makna dan ,isie keadilan ekologis. Perlu diingat bahwa ekokrasi adalah sarana menuju keadilan, dan makna keadilan sangat ditentukan oleh makna subyek-nya. Tanjakan ketiga dan keempat masuk dalam ranah teknis-kosmologis, terkait upaya menentukan cara dan sistem ekokrasi dalam suatu konteks. Yang perlu dicatat lebih dahulu adalah bahwa masalah ekologis sekarang ini sungguh bersifat global, tidak hanya lokal. Gejala munculnya pemanasan global dan perubahan iklim, serta juga munculnya lubang ozon, menunjukkan makin meluasnya permasalahan, dan sekaligus kompleksitasnya. ${ }^{34}$

Tanjakan terakhir, atau tanjakan kelima, tidak lagi mempersoalkan pertanyaan-pertanyaan filosofis. Pada ranah politis ini, seperti halnya demokrasi, yang perlu diwaspadai adalah jebakanjebakannya, atau penyimpangan-penyimpangan oleh individu, atau bahkan juga lembaga, yang dalam realitas sangat berpotensi membelokkan dan juga menyempitkan ekokrasi. Jebakan dan pembelokan ini sangat biasa terjadi mengingat bahwa kalau toh konsep dasar dan hukumnya disepakati, kesepakatan itu bersifat politis. Selalu masih ada orang atau pihak yang tidak puas. Mereka yang tidak mpuas akan terus berusaha memperjuangkan kepentingannya, dan hal itu bisa juga ditempuh pada ranah praktis ini. Seperti telah disebut di atas secara ringkas, setidaknya ada "ideologi ekstrem" yang akan laten menggoda manusia. Ideologi itu bolehlah disebut dengan anthroposentrisme, yang menempatkan manusia sebagai pusat kepentingan, dan kepentingan itu terfokus dan tereduksi pada kepentingan fisik. Yang

\footnotetext{
33 Al Andang L. Binawan, "Jalan Terjal Ekokrasi," Jurnal Hukum Lingkungan, Volume 1, Issue 1, 2014, hlm. 9

34 Ibid. hlm. 9-12
}

muncul adalah ekonomisme dan teknologisme. Ekonomisme (dengan kapitalisme sebagai puncaknya) akan menempatkan kepentingan ekonomis, yaitu profit atau keuntungan untuk manusia sebagai fokus, yang didukung oleh teknologi. Teknologisme dengan gampang jatuh pada kesadaran bahwa alam hanya ibarat sebuah mesin sebagai sarana. Dalam konteks ini, pandangan tentang waktu menjadi pendek, sehingga juga tidak menempatkan generasi yang akan datang dalam cakrawala kepentingan. ${ }^{35}$

Penegakan hukum lingkungan yang dilakukan lembaga formal, seperti pengadilan dan pemerintah yang selama ini belum bergesar dari pendekatan positivis formal dan prosedural. Aparat penegak hukum dalam merespon dan menyelesaikan berbagai persoalan lingkungan menunjukan sikap yang formalis, deterministik, dan memberi peluang terjadinya perilaku eksploitatif di kalangan pelaku usaha (investor). Instrumen hukum yang dipakai hanya berorientasi prosedur dan tidak dapat diandalkan sebagai pilar utama untuk mengatasi problem lingkungan, sementara pencemaran lingkungan dalam proses waktu semakin sulit untuk dapat dikendalikan. Oleh karena itu, pendekatan seperti itu kiranya perlu segera diakhiri, diganti dengan semangat pendekatan hukum progresif yang dimulai dari kesadaran yang tumbuh dari semua kalangan yang mempunyai kepedulian terhadap lingkungan untuk memahami bahwa persoalan lingkungan sudah mencapai tarap yang mengkhawatirkan. Untuk mengatasinya perlu dilakukan gerakan penyadaran secara progresif dengan melibatkan pertisipasi masyarakat, aparat penegak hukum, dan pemerintah akan tugas dan tangung jawabnya dalam menyelesaikan dan memecahkan masalahmasalah lingkungan. Dalam konteks ini untuk dapat menjalankan hukum lingkungan di tengah masyarakat yang penuh dengan kompleksitas, dibutuhkan aparat penegak hukum, yakni polisi, jaksa, dan hakim yang mempunyai visi, komitmen yang kuat, dan pengetahuan yang memadai di bidang lingkungan. Karena itu, sudah saatnya perlu dilakukan rekrutmen dan pembinaan aparat penegak secara khusus, yang diharapkan dapat menjalankan tugas khusus dalam menangani sengketa ataupun pengaduan masyarakat masalah lingkungan, berupa perusakan atau pencemaran lingkungan. Hakim yang diangkat atau ditunjuk

$35 \quad$ Ibid., hlm. 13-14 
dapat saja direkrut dari kalangan akademisi atau pakar hukum lingkungan, praktisi yang mengetahui seluk-beluk masalah lingkungan, ataupun kalangan aktivis yang selama ini gigih memperjuangkan lingkungan. ${ }^{36}$

Menurut Hossen Nasr dalam sains modern kerusakan alam lingkungan mengalami problem tak terpecahkan. Alam lingkungan mengalami desakralisasi, yakni kehilangan pandangan spiritual-religius tentang tatanan alam lingkungan dan hubungan manusia dengannya. Solusinya adalah sakralisasi ualang alam lingkungan yang dapat dimulai dari tansformasi ilmu dan para pelaku ilmu, uatmanya dalam pendidikan ilmu. Salah satu agenda yang ditawarkan adalah tatanan alam lingkungan perlu dideskripsikan melalui metode ilmiah dan spiritual, penyeimbangan pengalaman kehidupan yang lebih baik, bermakna, berbasis hukum alam, harmoni dengan alam dan sesuai dengan pandangan wahyu,perlunya adanya integrasi ilmu (pendidikan dan pembelajaran) dengan nilai tauhid. ${ }^{37}$ Pendapat Hossen Nasr ini sejalan dengan pembekalan aparat penegak hukum dalam hal ini para pelaku ilmu dengan pengetahuan dan pemahaman lingkungan yang baik dalam penyelesaian sengketa lingkungan hidup termasuk dengan adanya pembekalan hakim dan kebijakan sertifikasi hakim lingkungan hidup dan juga terobosan dalam membentuk pengadilan khusus lingkungan hidup yang baik di Indonesia. Tugas hakim adalah menyelesaikan setiap perkara yang masuk, hakim dalam hal ini wajib membuat penyelesaian yang diinginkan oleh masyarakat pencari keadilan itu, berdasarkan hukum yang ditemukan atau dibentuknya sendiri. ${ }^{38}$

Pengertian judicial activism berangkat dari sebuah filosofi yang melandasi pembuatan putusan peradilan dengan didasarkan pada pertimbangan-pertimbangan putusan di antaranya pada pandangan hakim terhadap perkembangan baru aturan, dinamika hukum dan sebagainya. ${ }^{39}$ Peran judicial activism sangatlah penting terutama

36 Absori, "Penegakan Hukum Lingkungan pada Era Reformasi," Jurnal Ilmu Hukum, Op.Cit., hlm. 233234

37 Absori, "Epistemologi dan Legalisasi Hukum Transendental," Op. Cit., hlm. 26

38 Jonaedi Efendi, Rekonstruksi Dasar Pertimbangan Hukum Hakim Berbasis Nilai-Nilai Hukum dan Rasa Keadilan yang Hidup dalam Masyarakat, Depok: PrenadaMedia Group, 2018, hlm. 268

39 Indriati Amarini, Keaktifan Hakim dan Peradilan Administrasi, Purwokerto: UMP Press, 2017, hlm. 53 dalam bidang-bidang hukum yang menyangkut lingkungan hidup, pertambangan, kehutanan, dan lainnya yang berkaitan dengan tindakan pemerintah atau penguasa dan perlindungan hukum bagi masyarakat. ${ }^{40}$ Tugas hakim dalam mewujudkan keadilan tidak terlepas dari kualitas putusan yang dihasilkan. Seorang hakim selain learned in law juga harus skilled in law yakni harus paham benar terhadap substansi dan penerapan hukum dalam suatu kasus. Dari tangan hakim, ilmu hukum menjadi applied science. Para hakimlah yang memberi nyawa terhadap bunyi pasal undangundang dengan penerapan yang tidak berhenti pada bunyi konteks undang-undang namun juga mempertimbangkan aspek keadilan, kemanfaatan dan juga kepastian hukum. Oleh sebab itu hakim "are forever condemned for the rest of their lives to continue studying the law." ${ }^{4}$ Praktek judicial activism bagi hakim dalam menyelesaikan perkara lingkungan membuka peluang pada sumbersumber hukum yang sifatnya materiil dari faktorfaktor sosiologis antropologis. Salah satu persoalan yang dihadapi dalam sengketa lingkungan hidup adalah begitu kuatnya penetrasi kepentingan ekonomi yang kapitalistik dan ditopang polapola pemerintahan yang birokratik koruptif. Irvan Mawardi mengkonsepsikan pijakan transformatif bagi hakim dalam menyelesaikan sengketa lingkungan dengan perspektif transendental. Adapun transendensi bermakna teologis, yakni ketuhanan artinya beriman kepada Tuhan sebagai otoritas tertinggi. Menguji dan mengadili perkara lingkungan harus mengutamakan nilainilai transendental sebab objek yang menjadi sasaran adalah keselamatan dan keberlangsungan ekosistem alam yang merupakan ciptaan Sang Khalik. Menyelamatkan puluhan ribu hektar tuhan, ribuan mil laut yang di dalamnya terdapat jutaan ekosistem dan jutaan ribu kandungan alam bawah tanah melalui sebuah putusan memerlukan penghayatan dan pendalaman transendental antara Makhluk dan Sang Khalik. Putusan yang demikian harus memiliki bobot transendental dan keluar dari kerangka-kerangka pikir material positivistik. ${ }^{42}$

\footnotetext{
$40 \quad$ Ibid., hlm. 33

$41 \quad$ Ibid., hlm. 313

42 Irvan Mawardi, Paradigma Baru PTUN Respon Peradilan Administrasi Terhadap Demokratisasi, Yogyakarta: Thafa Media, 2016, hlm. 249
} 
Simpulan

Pertama,. Penerapan Surat Keputusan Mahkamah Agung Nomor 134/KMA/SK/IX/2011 yang mengharuskan perkara lingkungan hidup ditangani oleh hakim yang bersertifikat lingkungan. Seharusnya dengan hadirnya kebijakan ini, perkara lingkungan dapat terselesaikan di ranah litigasi dengan baik. Tetapi nyatanya tidak. Banyak putusan-putusan lingkungan yang diselesaikan oleh hakim bersertifikat lingkungan yang di dalamnya tetap tidak mencerminkan nilai-nilai ekosentris yang seharusnya lebih banyak diadopsi dalam isi putusan sebagai bagian pertimbangan hakim yang kritis. Padahal dengan hadirnya kebijakan hakim yang bersertifikat lingkungan semestinya membuka ruang penemuan hukum dan akses keadilan (access to justice) yang lebih besar. Pendekatan ekologis bernuansa transendental sehingga menjadikan hakim berpikir kritis sebelum memutus perkara yang berkaitan dengan lingkungan agaknya tidak terlaksana dengan baik. Pemahaman lingkungan dari hakim yang telah dibina dan diberikan sertifikasi lingkungan tidak dibarengi dengan pemupukan nilai-nilai ilahiah dan ekologis secara berbarengan dalam memutus perkara lingkungan hidup. Sehingga penyelesaian sengketa lingkungan hidup menjadi tidak maksimal.

Kedua,. Peran judicial activism sangatlah penting terutama dalam bidang-bidang hukum yang menyangkut lingkungan hidup. Para hakimlah yang memberi nyawa terhadap bunyi pasal undang-undang dengan penerapan yang tidak berhenti pada bunyi konteks undang-undang namun juga mempertimbangkan aspek keadilan, kemanfaatan dan juga kepastian hukum. Praktek judicial activism bagi hakim yang bersertifikat lingkungan dalam menyelesaikan perkara lingkungan mutlak diperlukan, yakni mengarah pada pijakan transformatif bagi hakim dalam menyelesaikan sengketa lingkungan dengan perspektif transendental. Menguji dan mengadili perkara lingkungan harus mengutamakan nilainilai transendental sebab objek yang menjadi sasaran adalah keselamatan dan keberlangsungan ekosistem alam yang merupakan ciptaan Sang Khalik. Hal ini sebagai pemenuhan hak spritual hakim yang bersertifikat lingkungan dalam memutus perkara lingkungan dalam rangka mewujudkan ekokrasi.

\section{Daftar Pustaka}

Buku

Absori, Penegakan Hukum Lingkungan \& Antisipasi dalam Era Perdagangan Bebas, Muhammadiyah University Press, Surakarta, 2001

AchmadAli, Menguak Teori Hukum (Legal Theory) dan Teori Peradilan (Judicialprudence) Termasuk Interpretasi Undang-Undang (Legisprudence), Kencana Prenada Media Group, Jakarta, 2009

Enrico Simanjuntak, Hukum Acara Peradilan Tata Usaha Negara (Transformasi dan Refleksi), Sinar Grafika, Jakarta, 2018

Indriati Amarini, Keaktifan Hakim dan Peradilan Administrasi, Purwokerto: UMP Press, 2017

Irvan Mawardi, Paradigma Baru PTUN Respon Peradilan Administrasi Terhadap Demokratisasi, Thafa Media, Yogyakarta 2016

Jimly Asshiddiqie, Konstitusi dan Konstitusionalisme Indonesia, Sinar Grafika, Jakarta, 2017

Jimly Asshiddiqie, Green Constitution (Nuansa Hijau Undang-Undang Dasar Negara Republik Indonesia Tahun 1945), Rajawali Pers, Jakarta, 2009

Koesnadi Hardjasoemantri dan Harry Supriyono, Hukum Lingkungan, Cetakan I, edisi ke-2, Universitas Terbuka, Jakarta, 2006

Muhammad Akib, Hukum Lingkungan Perspektif Global dan Nasional, PT. Raja Grafindo Persada, Jakarta, 2013

Jonaedi Efendi, Rekonstruksi Dasar Pertimbangan Hukum Hakim Berbasis Nilai-Nilai Hukum dan Rasa Keadilan yang Hidup dalam Masyarakat, PrenadaMedia Group, Depok, 2018

Rachel Carson, Musim Bunga yang Bisu, Yayasan Obor Indonesia, Jakarta, 1990

Rochmani, Safik Faozi, Adi Suliantoro, "Budaya Hukum Hakim dalam Penyelesaian Perkara Lingkungan Hidup di Pengadilan", Prosiding Seminar Nasional Multi Disiplin 
Penerapan Kebijakan Hakim Bersertifikat Lingkungan ...

Ilmu \& Call For Papers Unisbank Ke-2, Surat Keputusan Ketua Mahkamah Agung RI Unisbank Semarang, 28 Juli 2016

Soetadnyo Wignjosoebroto, Pergeseran Paradigma dalam Kajian Sosial dan Hukum, Setara Press, Malang, 2013

Sudikno Mertokusumo, Teori Hukum (Edisi Revisi), Cahaya Atma Pustaka, Yogyakarta, 2014

\section{Jurnal}

Absori, "Epistemologi dan Legalisasi Hukum Transendental," Hukum Transendental Pengembangan dan Penegakan Hukum di Indonesia

Absori, "Penegakan Hukum Lingkungan pada Era Reformasi," Jurnal Ilmu Hukum, Volume 8, Nomor 2, 2005

Bambang Yulianto, "Gugatan Class Action terhadap Pendirian Bangunan di Sepanjang Bantaran Sungai di Kota Surakarta," Tesis, Program Pascasarjana Universitas Muhammadiyah Surakarta, 2005

Eko Nurmardiansyah, "Eco-Philosophy dan Implikasinya dalam Politik Hukum Lingkungan di Indonesia," Jurnal Melintas, Volume 30, Nomor 1, 2014

Manventus Amos, La Sina, "Wisnu Wardana, Gugatan Class Action dalam Sengketa Lingkungan Hidup (Tinjauan Yuridis Atas Perma Nomor 1 tahun 2002)", Jurnal Beraja Niti, Volume3, Nomor 3, 2014

The Hon. Justice Brian J Preston, "Characteristic of Succesful Environmental Courts And Tribunals," Eco Forum Global Annual Conference Gulyang 2013: The 3rd Environmental Justice Seminar, Gulyang, Guizhou, China, 2013

U.Achmad, 2015, "Masyarakat Santri dan Revolusi Industri Pertambangan di Rembang dalam Perspektif Politik Ibn Khaldun," Jurnal J.Addin, Volume 9, Nomor 1

\section{Peraturan Perundang-Undangan}

Undang-Undang Dasar Republik Indonesia Tahun 1945

\section{Putusan Pengadilan}

Putusan Pengadilan Nomor 24/Pdt. G/2015/ PN.Plg

Putusan Pengadilan Nomor 51/Pdt/2016/PT. Plg
Surat Keputusan Ketua Mahkamah Agung RI Nomor: 36/KMA/SK/IX/2015 